\title{
Distribution patterns of settlement-stage juveniles of Girella punctata and Girella leonina on the rocky coast of the Kanto-Izu region, Japan
}

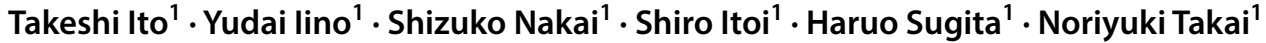

Received: 1 February 2018 / Accepted: 2 April 2018 / Published online: 9 May 2018

(c) The Author(s) 2018

\begin{abstract}
The early life history of girellid fishes in Japanese waters is unclear, and little is known about their species-specific reproductive strategies. We examined seasonal changes of distribution patterns for settlement-stage juveniles of Girella punctata and Girella leonina on the rocky shore in the regions of Kanto and Izu, Japan, to infer the influence of the Kuroshio Current on their reproduction. We collected 813 settlement-stage juveniles mainly in Sagami Bay and genetically identified the species. The juveniles of G. punctata were collected on the rocky shore in Sagami Bay during April to August, with the abundant catch in May and June. Thus, we infer that juvenile G. punctata ubiquitously inhabit the rocky shore in the area in spring and summer. By contrast, juveniles of G. leonina were rarely collected in Sagami Bay, with a total catch of only 66. Notably, no juveniles were collected during the wintertime in Sagami Bay, although an abundant catch of G. leonina had been previously reported for Sagami Nada off Sagami Bay during January to March. This clear-cut difference between the areas likely reflects the difference in proximity to the path of the Kuroshio Current. We expect that the Kuroshio Current strongly influences the reproductive success of G. leonina.
\end{abstract}

Keywords Girellid juvenile $\cdot$ Reproductive strategy $\cdot$ Kuroshio $\cdot$ Sagami Bay $\cdot$ Sagami Nada $\cdot$ Mitochondrial DNA Polymerase chain reaction $\cdot$ Restriction fragment length polymorphism

\section{Introduction}

Largescale blackfish Girella punctata and smallscale blackfish G. leonina (Perciformes, Girellidae) are demersal fish inhabiting the coastal rocky bottom zone around Japan. Both species are commercially important in coastal fisheries, and also very popular with anglers. However, in many respects the habitat use of these species throughout their life history remains unknown. Precise understanding of their habitat use is essential for stock management and sustainable use of this resource.

The geographical distributions of these species largely overlap in the western North Pacific, but G. leonina is distributed a little more to the south than G. punctata. The

Noriyuki Takai

takai@brs.nihon-u.ac.jp

1 Department of Marine Science and Resources, College of Bioresource Sciences, Nihon University, 1866 Kameino, Fujisawa, Kanagawa 252-0880, Japan northern extremity of the distribution on the Pacific side of Japan is the coastal waters of the Boso Peninsula for both species (Nakabo 2000), whereas the northern extremity in the Sea of Japan is thought to slightly differ: the coastal waters of the Niigata Prefecture for G. punctata and the Tsushima Strait for G. leonina (Yagishita and Nakabo 2000). Similarly, the southernmost distribution area of $G$. leonina (off Fujian, China) is supposedly located to the south of the southernmost area of G. punctata (off Hong Kong, China) (Nakabo 2000).

In contrast to the distributions of the adults, little is known about geographical distributions of juveniles in both species. Such poor information about the juveniles may be caused by the difficulty in species identification of juveniles. Generally, morphological discrimination of $G$. punctata and G. leonina is mainly based on the shape of the caudal fin, the number of scales, and pigmentation patterns (Araga 1997; Yagishita and Nakabo 2000), but these morphological criteria are unreliable in identifying juveniles (Fujita et al. 2000). Therefore, Itoi et al. (2007) developed a simple and highly sensitive method for 
separating these two species, using polymerase chain reaction (PCR) and restriction fragment length polymorphism (RFLP) analysis of mitochondrial DNA (mtDNA).

Nakai et al. (2015) utilized this method to identify small juveniles of the girellid fish with $<25 \mathrm{~mm}$ standard length (SL), collected from the littoral zones of rocky shores and drifting seaweeds in Sagami Nada around Shimoda, the southeastern Izu Peninsula, and found marked seasonal changes in the species compositions. In this area, the juveniles of $G$. punctata mostly appeared from May to July with the peak in June, while juveniles of G. leonina mostly appeared from January to May (Nakai et al. 2015). A similar time lag in the appearance of these two species was found for the fish with 10-80 mm SL, collected in the coastal waters of the Izu Peninsula (Mano and Itoi 2011). These previous studies have suggested that the interspecific differences in the seasonal occurrence of juveniles probably reflect the difference of their spawning seasons: February to June in G. punctata (Araga 1997; Konishi 2014a) and November to December (Araga 1997) or October to February (Konishi 2014b) in G. leonina.

In the present study, we focused on the general distribution patterns of the settlement-stage juveniles of these two girellid species around the rocky shore in the Kanto-Izu region. Our recent maturity analysis of adult fish suggested that $G$. punctata spawns during spring in various places around Kyushu and the southern part of Honshu (mainland) (Nakai et al. 2015; Takai et al. 2017), whereas the spawning ground of $G$. leonina might possibly be located in the southernmost distribution area of the species, which is located in the upstream region of the Kuroshio Current (Takai et al. 2017). If that is the case, the Kuroshio Current would transport eggs, larvae, and juveniles of $G$. leonina to the coastal waters of the Japanese Archipelago and enable juvenile settlement along the coast of Japan. Accordingly, we expect that the juvenile distribution of $G$. leonina would be closely related to the Kuroshio Current.

In this study, we examined the seasonal changes in the juvenile distributions of G. punctata and G. leonina on the rocky shore in Sagami Bay, between the easternmost part of the Izu Peninsula and the southernmost part of the Miura Peninsula, to infer the influence of the Kuroshio Current on the reproduction of these species. Sagami Bay is not directly exposed to the Kuroshio Current, in contrast to Sagami Nada. If the Kuroshio Current strongly influences the juvenile distribution of G. leonina, it can be assumed that the species compositions of the juveniles are different between Sagami Bay and Sagami Nada. Here we also examined the distributions of the juveniles in the coastal waters of the southern Boso Peninsula and the inner part of Tokyo Bay as a supplementary research to better understand the influence of the Kuroshio Current.

\section{Materials and methods}

\section{Sampling and measurement of fish}

Juveniles of the girellid fish were collected using hand nets (3-mm-mesh aperture) around the rocky shore at eight stations (S1-S5, B1, B2, and Y; Fig. 1). In the northeastern area of Sagami Bay, multi-year monthly surveys were conducted at two stations: S1 (Hayama) from April 2012 to March 2015 and S2 (Enoshima) from June 2012 to March 2015. Year-round monthly surveys were conducted at S3 (Jogashima) around the southernmost tip of the Miura Peninsula from November 2014 to November 2015, and S4 (Ito) around the eastern edge of the Izu Peninsula from April 2016 to December 2017. As a supplementary survey, we also conducted bimonthly sampling at two stations in the Boso Peninsula: B1 (Kamogawa) from February to August in 2015 and B2 (Tateyama) from April to August in 2015. In addition, we also conducted one-off supplementary surveys at S5 (Oiso) in the northern area of Sagami Bay in July 2012 and July 2015 and Y (Yokohama) to the north of the Uraga Channel in June 2014 and September 2014. The sampling was carried out in the intertidal zone at low tide during the spring tide.

The collected fish were measured for SL (millimeters) and wet weight (BW; grams), and subsequently fixed with $99.5 \%$ ethanol solution. The condition factor $(K)$ of the fish was calculated for both species by the following formula: $K=\mathrm{BW} / \mathrm{SL}^{3} \times 10^{5}$.

We also analyzed the body size distribution and the $K$ of the juveniles collected on the rocky shore of Shimoda (station I) in Sagami Nada by Nakai et al. (2015). However, $K$ could not be calculated for some of the juveniles from Shimoda, since the data of body weight were invalid for those individuals.

\section{DNA extraction, PCR amplification, and PCR product sequencing}

Identification of species was carried out on the basis of the discrimination method using PCR-RFLP of mtDNA reported by Itoi et al. (2007). A total of 30 individuals were randomly chosen and analyzed from each station every month, when abundant specimens were collected. In cases of smaller sample size with $<30$ individuals, all the individuals were genetically analyzed.

Total genomic DNA was extracted from the skeletal muscle of all the analyzed juveniles using the method of Sezaki et al. (1999). DNA fragments corresponding to the control region and the $16 \mathrm{~S}$ ribosomal RNA (16S rRNA) gene in mtDNA were amplified by PCR. Primers 
Fig. 1 Study area. Year-round monthly sampling was conducted at five stations (open circles S1-S4 and I). Supplementary sampling was conducted at four stations (open squares S5, $\mathrm{B} 1, \mathrm{~B} 2$, and $\mathrm{Y}$ )

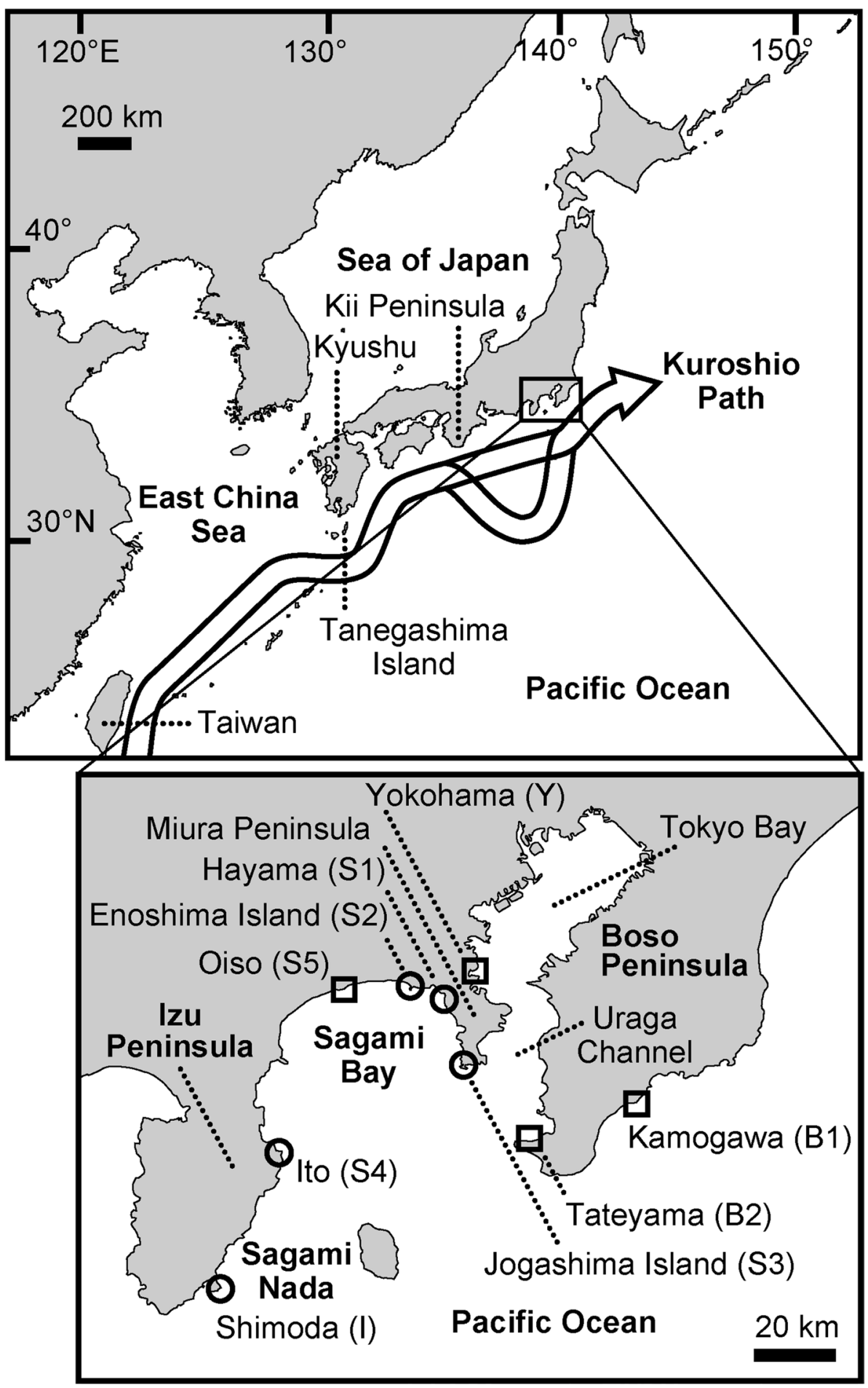

16SAR-L (5'-CGCCTGTTTATCAAAAAC AT-3') and 16SBR-H (5'-CCGGTCTGAACTCAGATCACGT-3') were used to amplify the partial 16S rRNA gene fragment, following Palumbi et al. (1991). Primers fDloop_F (5'-TTCCTGGCATTTGGTTCCTACTTCAG-3') and ftRPhe_R (5'-CCATCTT AACATCTTCAGTGTTATG C-3') were used to amplify the partial control region flanked by part of a transfer RNA gene, following Itoi et al. (2007). PCR amplification was performed using a reaction mixture containing genomic DNA as a template, 1 unit of GoTaq Flexi DNA polymerase (Promega, USA), $4 \mu$ l of $5 \times$ Green GoTaq Flexi Buffer (Promega), $2.6 \mu \mathrm{l}$ of $5 \mu \mathrm{M}$ primers, $1.6 \mu \mathrm{l}$ of $2.5 \mathrm{mM}$ deoxyribonucleotide triphosphate mix and $2 \mu \mathrm{l}$ of $25 \mathrm{mM} \mathrm{MgCl}_{2}$, and 
the total volume was brought to $20 \mu \mathrm{l}$ with sterile water. The thermal cycling profile of PCR consisted of an initial denaturation at $95^{\circ} \mathrm{C}$ for $1 \mathrm{~min}$, followed by 35 cycles of denaturation at $95^{\circ} \mathrm{C}$ for $10 \mathrm{~s}$, annealing at $55^{\circ} \mathrm{C}$ for $30 \mathrm{~s}$, and extension at $72{ }^{\circ} \mathrm{C}$ for $45 \mathrm{~s}$.

The RFLP analysis of the gene products was performed by digesting $5 \mu \mathrm{l}$ of each amplified product with 10 units of restriction enzyme: HinfI (Nippongene, Japan) for $16 \mathrm{~S}$ rRNA and $\mathrm{Xba \textrm {I }}$ (Nippongene) for the control region (Fig. 2). The reaction was carried out at $37{ }^{\circ} \mathrm{C}$ for $1 \mathrm{~h}$ in a reaction mixture containing buffer supplied with the kit. The digested samples were subjected to electrophoresis on a 3\% agarose gel and stained with Midori Green DNA Stain (NIPPON Genetics, Japan).

\section{Statistical analysis}

The body size (SL) and the $K$ were compared between $G$. punctata and G. leonina using Mann-Whitney's $U$-test. The temporal changes in the body size of the juveniles were analyzed using Pearson's correlation coefficient $(r)$ and its significance test. Statistical analysis was performed using Excel Statistics 2012 (Social Survey Research Information, Japan).

\section{Results}

\section{Species composition in Sagami Bay}

A total of 2467 girellid juveniles were collected around the rocky shore in Sagami Bay from April 2012 to December 2017. We examined the species composition of 744 juveniles, using the species discrimination method of mtDNA by PCR-RFLP, and found there was a marked interspecific difference in the occurrence frequency between $G$. punctata and $G$. leonina. The analyzed juveniles consisted mostly of G. punctata $(n=676)$, which comprised $90.9 \%$ of all the 744 individuals. By contrast, G. leonina totaled 66 individuals only in the bay.

In the multi-year monthly research during 2012-2015 at two northeastern stations, S1 (Hayama) and S2 (Enoshima), we collected 777 girellid juveniles at S1 from April 2012 to June 2014 (Table 1) and 376 juveniles at S2 from June 2012 to June 2014 (Table 2). A total of 250 individuals at S1 and 146 individuals at $\mathrm{S} 2$ were genetically analyzed for species identification, respectively. As a result, the species compositions at these stations were characterized by a seasonally frequent occurrence of G. punctata and a rare occurrence of $G$. leonina. The 250 juveniles collected at $\mathrm{S} 1$ consisted of 245 G. punctata $(98.0 \%)$ and five G. leonina (2.0\%) (Table 1). Similarly, the 146 juveniles collected at S2 consisted of 139 G. punctata (95.2\%) and seven G. leonina (4.8\%) (Table 2).
Fig. 2 Typical polymerase chain reaction-restriction fragment length polymorphism (PCRRFLP) profiles of the $16 \mathrm{~S}$ ribosomal RNA (16S rRNA) gene and the control region obtained from Girella punctata and Girella leonina. PCR products for the 16S rRNA gene were treated with HinfI (upper panel), whereas those for the control region were digested with XbaI (lower panels). The restriction fragments are marked by arrows. Lanes $1-5 G$. leonina, lanes 6-8 G. punctata, lane $M$ molecular size marker (100-bp ladder)
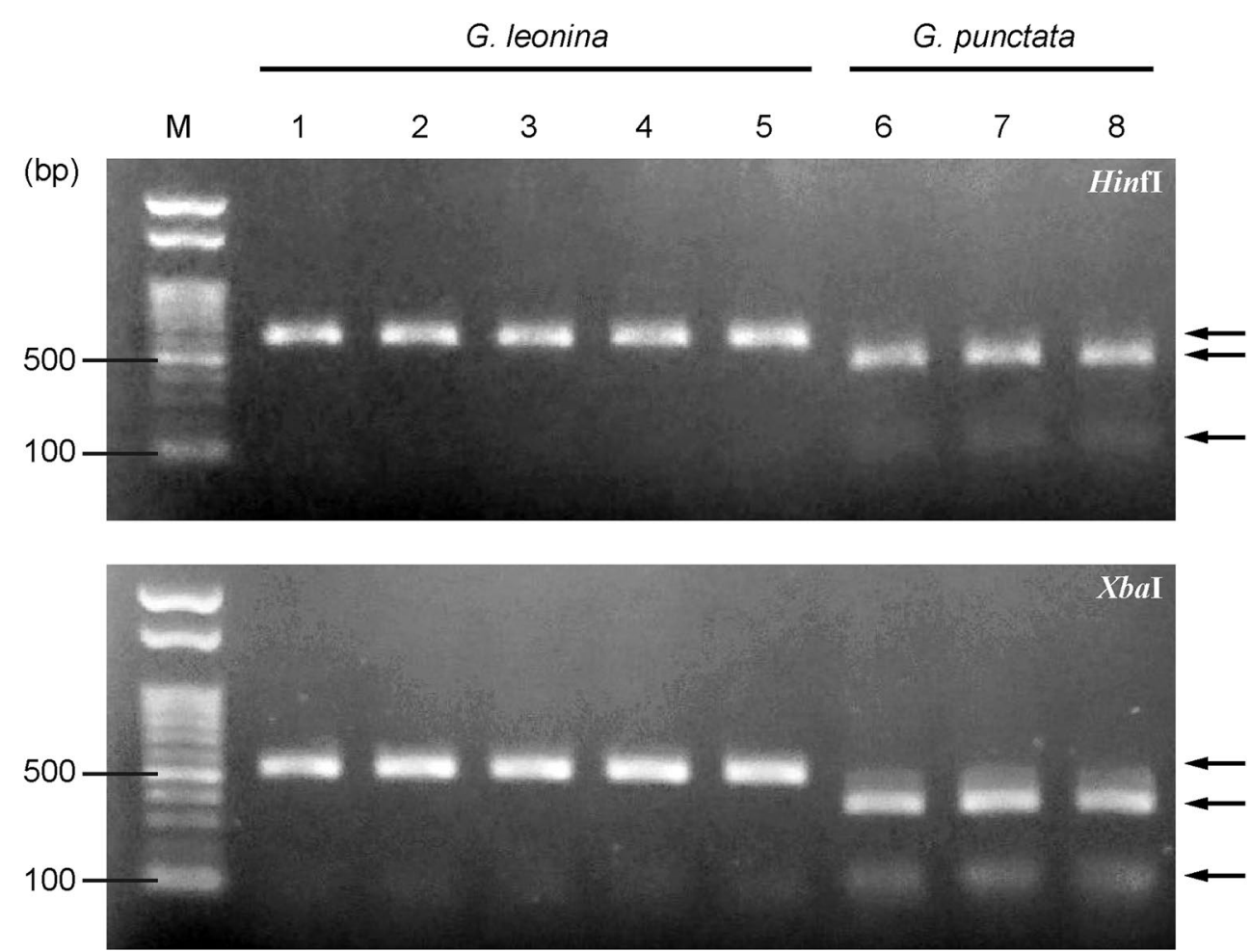
Table 1 Species composition and body size (standard length; $S L$ ) of juveniles of girellid fish collected in Hayama (S1) based on polymerase chain reactionrestriction fragment length polymorphism (PCR-RFLP) of mitochondrial DNA (mtDNA)

\begin{tabular}{|c|c|c|c|c|c|c|c|c|}
\hline \multirow[t]{3}{*}{ Month } & \multirow[t]{3}{*}{$n_{1}$} & \multirow[t]{3}{*}{$n_{2}$} & \multicolumn{3}{|c|}{ Girella punctata } & \multicolumn{3}{|c|}{ Girella leonina } \\
\hline & & & \multirow[t]{2}{*}{$n$} & \multicolumn{2}{|l|}{$\mathrm{SL}(\mathrm{mm})$} & \multirow[t]{2}{*}{$n$} & \multicolumn{2}{|l|}{$\mathrm{SL}(\mathrm{mm})$} \\
\hline & & & & Mean \pm SD & Min.-max. & & Mean \pm SD & Min.-max. \\
\hline \multicolumn{9}{|l|}{2012} \\
\hline April & 1 & 1 & 0 & - & - & 1 & 31.9 & - \\
\hline May & 276 & 30 & 30 & $14.9 \pm 1.5$ & $12.7-18.7$ & 0 & - & - \\
\hline June & 13 & 13 & 13 & $19.0 \pm 3.0$ & $15.9-24.2$ & 0 & - & - \\
\hline July & 0 & 0 & 0 & - & - & 0 & - & - \\
\hline August & 0 & 0 & 0 & - & - & 0 & - & - \\
\hline September & 0 & 0 & 0 & - & - & 0 & - & - \\
\hline October & n.s. & - & - & - & - & - & - & - \\
\hline November & 0 & 0 & 0 & - & - & 0 & - & - \\
\hline December & 0 & 0 & 0 & - & - & 0 & - & - \\
\hline \multicolumn{9}{|l|}{2013} \\
\hline January & 0 & 0 & 0 & - & - & 0 & - & - \\
\hline February & 0 & 0 & 0 & - & - & 0 & - & - \\
\hline March & 0 & 0 & 0 & - & - & 0 & - & - \\
\hline April & 146 & 30 & 30 & $16.1 \pm 1.1$ & $14.1-18.1$ & 0 & - & - \\
\hline May & 107 & 30 & 30 & $19.3 \pm 2.8$ & $14.7-25.4$ & 0 & - & - \\
\hline June & 38 & 30 & 30 & $16.8 \pm 2.1$ & $12.6-23.2$ & 0 & - & - \\
\hline July & 29 & 29 & 29 & $23.8 \pm 6.3$ & $16.2-46.5$ & 0 & - & - \\
\hline August & 0 & 0 & 0 & - & - & 0 & - & - \\
\hline September & 0 & 0 & 0 & - & - & 0 & - & - \\
\hline October & 0 & 0 & 0 & - & - & 0 & - & - \\
\hline November & 0 & 0 & 0 & - & - & 0 & - & - \\
\hline December & 0 & 0 & 0 & - & - & 0 & - & - \\
\hline \multicolumn{9}{|l|}{2014} \\
\hline January & 0 & 0 & 0 & - & - & 0 & - & - \\
\hline February & 0 & 0 & 0 & - & - & 0 & - & - \\
\hline March & 0 & 0 & 0 & - & - & 0 & - & - \\
\hline April & 27 & 27 & 25 & $15.8 \pm 1.3$ & $13.5-20.0$ & 2 & $15.9 \pm 0.6$ & $15.4-16.3$ \\
\hline May & 105 & 30 & 28 & $17.8 \pm 2.0$ & $14.8-21.6$ & 2 & $21.5 \pm 3.8$ & $18.8-24.2$ \\
\hline June & 39 & 30 & 30 & $21.3 \pm 3.0$ & $14.0-26.0$ & 0 & - & - \\
\hline July & 0 & 0 & 0 & - & - & 0 & - & - \\
\hline August & 0 & 0 & 0 & - & - & 0 & - & - \\
\hline September & 0 & 0 & 0 & - & - & 0 & - & - \\
\hline October & 0 & 0 & 0 & - & - & 0 & - & - \\
\hline November & 0 & 0 & 0 & - & - & 0 & - & - \\
\hline December & 0 & 0 & 0 & - & - & 0 & - & - \\
\hline \multicolumn{9}{|l|}{2015} \\
\hline January & 0 & 0 & 0 & - & - & 0 & - & - \\
\hline February & 0 & 0 & 0 & - & - & 0 & - & - \\
\hline March & 0 & 0 & 0 & - & - & 0 & - & - \\
\hline Total & 777 & 250 & 245 & $18.3 \pm 4.0$ & $12.6-46.5$ & 5 & $21.3 \pm 6.8$ & $15.4-31.9$ \\
\hline
\end{tabular}

$n_{1}$ Total catch of girellid juveniles, $n_{2}$ total individuals analyzed for DNA, n.s. no sampling because of rough weather, Min. minimum, max. maximum
The species composition at S3 (Jogashima), located around the southernmost tip of the Miura Peninsula, was slightly different from those at S1 and S2. We collected a total of 365 juveniles from May to August 2015 by year-round sampling during November 2014 to November 2015, and genetically identified the species of 107 individuals (Table 3). The analyzed juveniles consisted of $91 \mathrm{G}$. punctata and 15 G. leonina. The composition ratio of $14.0 \%$ 
Table 2 Species composition and body size (SL) of juveniles of girellid fish collected in Enoshima (S2) based on PCRRFLP of mtDNA

\begin{tabular}{|c|c|c|c|c|c|c|c|c|}
\hline \multirow[t]{3}{*}{ Month } & \multirow[t]{3}{*}{$n_{1}$} & \multirow[t]{3}{*}{$n_{2}$} & \multicolumn{3}{|c|}{ G. punctata } & \multicolumn{3}{|c|}{ G. leonina } \\
\hline & & & \multirow[t]{2}{*}{$n$} & \multicolumn{2}{|l|}{$\mathrm{SL}(\mathrm{mm})$} & \multirow[t]{2}{*}{$n$} & \multicolumn{2}{|l|}{$\mathrm{SL}(\mathrm{mm})$} \\
\hline & & & & Mean \pm SD & Min.-max. & & Mean \pm SD & Min.-max. \\
\hline \multicolumn{9}{|l|}{2012} \\
\hline June & 28 & 28 & 28 & $22.3 \pm 4.3$ & $16.8-34.4$ & 0 & - & - \\
\hline July & n.s. & - & - & - & - & - & - & - \\
\hline August & 0 & 0 & 0 & - & - & 0 & - & - \\
\hline September & n.s. & - & - & - & - & - & - & - \\
\hline November & 0 & 0 & 0 & - & - & 0 & - & - \\
\hline December & 0 & 0 & 0 & - & - & 0 & - & - \\
\hline \multicolumn{9}{|l|}{2013} \\
\hline January & 0 & 0 & 0 & - & - & 0 & - & - \\
\hline February & n.s. & - & - & - & - & - & - & - \\
\hline March & 0 & 0 & 0 & - & - & 0 & - & - \\
\hline April & n.s. & - & - & - & - & - & - & - \\
\hline May & 137 & 30 & 27 & $21.0 \pm 1.8$ & $17.5-24.5$ & 3 & $21.4 \pm 1.4$ & $20.0-22.8$ \\
\hline June & 117 & 30 & 29 & $22.5 \pm 7.1$ & $12.3-36.8$ & 1 & 26.5 & - \\
\hline July & 66 & 30 & 30 & $21.5 \pm 3.9$ & $12.5-31.6$ & 0 & - & - \\
\hline August & 4 & 4 & 4 & $32.6 \pm 3.4$ & $29.5-37.1$ & 0 & - & - \\
\hline September & 0 & 0 & 0 & - & - & 0 & - & - \\
\hline October & n.s. & - & - & - & - & - & - & - \\
\hline November & n.s. & - & - & - & - & - & - & - \\
\hline December & n.s. & - & - & - & - & - & - & - \\
\hline \multicolumn{9}{|l|}{2014} \\
\hline January & 0 & 0 & 0 & - & - & 0 & - & - \\
\hline February & 0 & 0 & 0 & - & - & 0 & - & - \\
\hline March & n.s. & - & - & - & - & - & - & - \\
\hline April & 0 & 0 & 0 & - & - & 0 & - & - \\
\hline May & n.s. & - & - & - & - & - & - & - \\
\hline June & 24 & 24 & 21 & $20.6 \pm 3.9$ & $16.1-31.6$ & 3 & $30.1 \pm 3.1$ & $26.8-33.0$ \\
\hline July & 0 & 0 & 0 & - & - & 0 & - & - \\
\hline August & 0 & 0 & 0 & - & - & 0 & - & - \\
\hline September & 0 & 0 & 0 & - & - & 0 & - & - \\
\hline October & 0 & 0 & 0 & - & - & 0 & - & - \\
\hline November & 0 & 0 & 0 & - & - & 0 & - & - \\
\hline December & 0 & 0 & 0 & - & - & 0 & - & - \\
\hline \multicolumn{9}{|l|}{2015} \\
\hline January & 0 & 0 & 0 & - & - & 0 & - & - \\
\hline February & 0 & 0 & 0 & - & - & 0 & - & - \\
\hline March & 0 & 0 & 0 & - & - & 0 & - & - \\
\hline Total & 376 & 146 & 139 & $21.9 \pm 4.9$ & $12.3-37.1$ & 7 & $25.8 \pm 4.8$ & $20.0-33.0$ \\
\hline
\end{tabular}

For abbreviations, see Table 1

for $G$. leonina at this station was higher than the ratios at the two northeastern stations, $\mathrm{S} 1$ and $\mathrm{S} 2$.

A further difference in the composition of species was found for the juveniles collected at S4 (Ito), located around the eastern edge of the Izu Peninsula and the westernmost area of Sagami Bay. In the monthly sampling from April 2016 to December 2017, we collected a total of 855 girellid juveniles, and genetically identified the species of 205 individuals (Table 3). The analyzed juveniles consisted of 167 G. punctata (81.5\%) and 38 G. leonina (18.5\%). The composition ratio for $G$. leonina at this station was highest in Sagami Bay.

In the supplementary sampling at S5 (Oiso), located on the northern coast of Sagami Bay, we collected a total of 94 
Table 3 Species composition and body size (SL) of juveniles of girellid fish collected in Jogashima (S3), Ito (S4), and Oiso (S5), based on PCR-RFLP of mtDNA

\begin{tabular}{|c|c|c|c|c|c|c|c|c|}
\hline \multirow[t]{3}{*}{ Month } & \multirow[t]{3}{*}{$n_{1}$} & \multirow[t]{3}{*}{$n_{2}$} & \multicolumn{3}{|c|}{ G. punctata } & \multicolumn{3}{|c|}{ G. leonina } \\
\hline & & & \multirow[t]{2}{*}{$n$} & \multicolumn{2}{|l|}{$\mathrm{SL}(\mathrm{mm})$} & \multirow[t]{2}{*}{$n$} & \multicolumn{2}{|l|}{$\mathrm{SL}(\mathrm{mm})$} \\
\hline & & & & Mean \pm SD & Min.-max. & & Mean \pm SD & Min.-max. \\
\hline \multicolumn{9}{|l|}{ Jogashima (S3) } \\
\hline \multicolumn{9}{|l|}{2014} \\
\hline November & 0 & 0 & - & - & - & - & - & - \\
\hline December & 0 & 0 & - & - & - & - & - & - \\
\hline \multicolumn{9}{|l|}{2015} \\
\hline January & 0 & 0 & - & - & - & - & - & - \\
\hline February & 0 & 0 & - & - & - & - & - & - \\
\hline March & 0 & 0 & - & - & - & - & - & - \\
\hline April & 0 & 0 & - & - & - & - & - & - \\
\hline May & 73 & 30 & 16 & $20.2 \pm 1.7$ & $16.3-23.1$ & 14 & $22.9 \pm 2.9$ & 17.9-28.6 \\
\hline June & 101 & 30 & 29 & $22.9 \pm 3.4$ & $17.9-29.7$ & 1 & 30.3 & - \\
\hline July & 174 & 30 & 30 & $18.3 \pm 2.0$ & $15.3-25.9$ & 0 & - & - \\
\hline August & 17 & $17^{\mathrm{a}}$ & 16 & $34.0 \pm 6.4$ & $20.1-44.9$ & 0 & - & - \\
\hline September & 0 & 0 & - & - & - & - & - & - \\
\hline October & 0 & 0 & - & - & - & - & - & - \\
\hline November & 0 & 0 & - & - & - & - & - & - \\
\hline Total & 365 & 107 & 91 & $22.9 \pm 6.5$ & $15.3-44.9$ & 15 & $23.4 \pm 3.4$ & $17.9-30.3$ \\
\hline \multicolumn{9}{|l|}{ Ito (S4) } \\
\hline \multicolumn{9}{|l|}{2016} \\
\hline April & 6 & 6 & 6 & $21.9 \pm 4.9$ & $16.0-30.4$ & 0 & - & - \\
\hline May & 66 & 30 & 28 & $16.3 \pm 1.4$ & $13.9-19.4$ & 2 & $20.8 \pm 1.3$ & $19.8-21.7$ \\
\hline June & 222 & 30 & 30 & $15.4 \pm 1.8$ & $11.6-22.1$ & 0 & - & - \\
\hline July & 84 & 30 & 30 & $17.8 \pm 2.3$ & $12.9-22.0$ & 0 & - & - \\
\hline August & 0 & 0 & - & - & - & - & - & - \\
\hline September & 0 & 0 & - & - & - & - & - & - \\
\hline October & 0 & 0 & - & - & - & - & - & - \\
\hline November & 0 & 0 & - & - & - & - & - & - \\
\hline December & 0 & 0 & - & - & - & - & - & - \\
\hline \multicolumn{9}{|l|}{2017} \\
\hline January & 0 & 0 & - & - & - & - & - & - \\
\hline February & 0 & 0 & - & - & - & - & - & - \\
\hline March & 12 & 12 & 0 & - & - & 12 & $23.6 \pm 3.3$ & $18.3-30.2$ \\
\hline April & 7 & 7 & 0 & - & - & 7 & $20.3 \pm 3.2$ & $16.5-25.5$ \\
\hline May & 34 & 30 & 14 & $18.5 \pm 2.4$ & $16.7-25.4$ & 16 & $19.1 \pm 1.9$ & $16.9-23.8$ \\
\hline June & 100 & 30 & 29 & $19.5 \pm 2.1$ & $16.8-25.9$ & 1 & 18.0 & - \\
\hline July & 324 & 30 & 30 & $21.1 \pm 4.3$ & $15.8-31.8$ & 0 & - & - \\
\hline August & 0 & 0 & - & - & - & - & - & - \\
\hline September & 0 & 0 & - & - & - & - & - & - \\
\hline October & 0 & 0 & - & - & - & - & - & - \\
\hline November & 0 & 0 & - & - & - & - & - & - \\
\hline December & 0 & 0 & - & - & - & - & - & - \\
\hline Total & 805 & 205 & 167 & $18.2 \pm 3.4$ & $11.6-31.8$ & 38 & $20.8 \pm 3.2$ & $16.5-30.2$ \\
\hline \multicolumn{9}{|l|}{ Oiso (S5) } \\
\hline \multicolumn{9}{|l|}{2012} \\
\hline July & 88 & 30 & 30 & $30.1 \pm 3.4$ & $24.5-36.5$ & 0 & - & - \\
\hline July & 6 & $6^{\mathrm{a}}$ & 4 & $27.6 \pm 7.9$ & $21.2-37.9$ & 1 & 46.8 & - \\
\hline Total & 94 & 36 & 34 & $29.8 \pm 4.1$ & $21.2-37.9$ & 1 & 46.8 & - \\
\hline
\end{tabular}


Table 3 (continued)

For abbreviations, see Table 1

${ }^{\text {a }}$ Species of one individual could not be identified because of degradation of DNA

girellid juveniles in July 2012 and July 2015, and genetically identified the species of 36 individuals (Table 3 ). There was a marked interspecific difference in the occurrence frequency, similar to the results at the northeastern stations, $\mathrm{S} 1$ and S2. The analyzed 36 juveniles consisted of $34 \mathrm{G}$. punctata (94\%) and one G. leonina (3\%).

\section{Occurrence season in Sagami Bay}

During the research period in Sagami Bay, the G. punctata juveniles were collected on the rocky shore from April to August and the $G$. leonina juveniles were collected from March to July (Fig. 3; Tables 1, 2 and 3). Neither of these
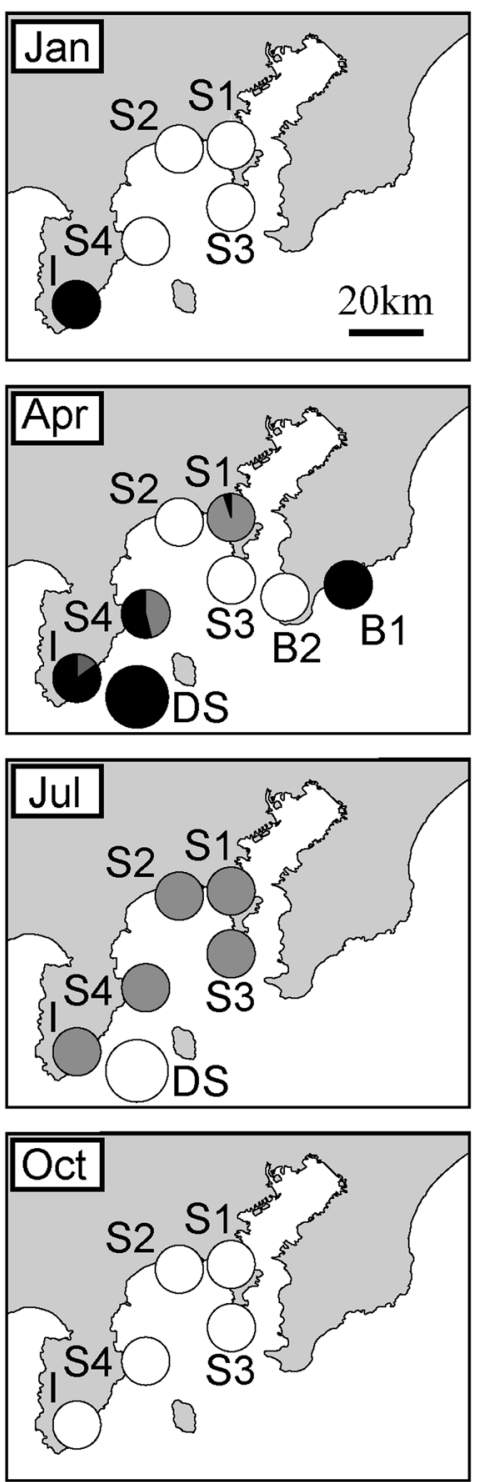
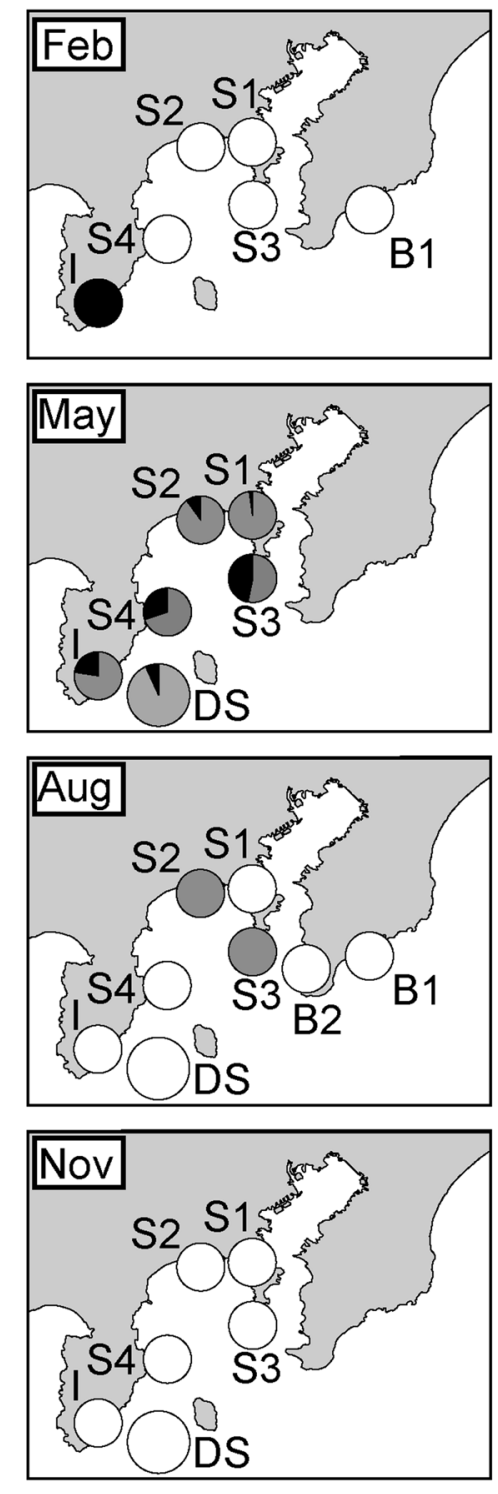
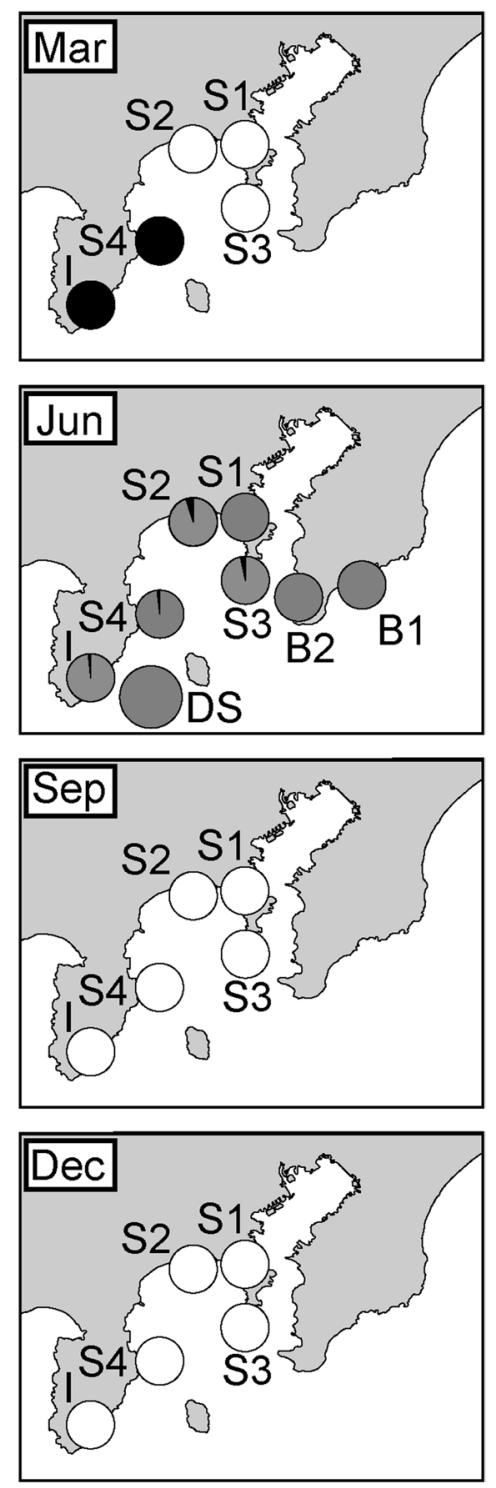

\section{G. punctata}

G. leonina

Fig. 3 Seasonal changes in the species composition of the girellid juveniles collected from the rocky shore in Sagami Bay, Sagami Nada, and the coastal zone of the Boso Peninsula. The distributions are shown for the integrated data of S1 (2012-2015), S2 (20122015), S3 (2014-2015), S4 (2016-2017), B1 (2015), and B2 (2015) in the present research and I (2011-2012) in Nakai et al. (2015). The species composition of the juveniles collected from drifting seaweeds $(D S)$ in Sagami Nada by Nakai et al. (2015) is also shown with larger circles 
species was collected from September to February at any station. The occurrence season of G. punctata locally varied with sampling stations, but the time lag was only 1 month: April-July at S1 and S4 and May-August at S2 and S3. Nakai et al. (2015) collected planktonic juveniles of G. punctata in May and June from drifting seaweeds in Sagami Nada off Shimoda, the southeastern part of the Izu Peninsula, and settlement-stage juveniles from April to July on the rocky shore of Shimoda. Thus, the occurrence season of G. punctata juveniles in Sagami Bay was highly consistent with the occurrence season in Sagami Nada.

On the other hand, the occurrence season of the $G$. leonina juveniles in eastern Sagami Bay (S1-S3) was markedly different from that in Sagami Nada (Fig. 3). The G. leonina juveniles in Sagami Nada were collected from January to June, and particularly during January to March G. leonina singly comprised the girellid juveniles (Nakai et al. 2015). By contrast, the G. leonina juveniles in the eastern Sagami Bay were collected during April to May at $\mathrm{S} 1$ and May to June at $\mathrm{S} 2$ and $\mathrm{S} 3$, and juveniles of $G$. leonina were not collected from January to March.

At the eastern edge of the Izu Peninsula (S4), the juveniles of $G$. leonina were collected for 4 months from March to June, longer than the duration at S1 (April-May), and S2 and S3 (May-June) (Fig. 3). The catch of G. leonina in March was earliest in Sagami Bay, and thus the occurrence season at S4 was intermediate between Sagami Nada (Shimoda) and eastern Sagami Bay.

\section{Occurrence of juveniles in the other areas}

In the bimonthly sampling at B1 (Kamogawa), located on the Pacific coast of the Boso Peninsula, we collected a total of 231 girellid juveniles in April and June, but no girellid juvenile was collected in February and August (Fig. 3; Table 4). DNA analysis of 30 individuals collected in April and June showed G. leonina only in April and G. punctata only in June. That is, the percentage of each species throughout the research period was equal at $50 \%$. On the other hand, only eight girellid juveniles were collected at B2 (Tateyama), located around the southernmost area of the Uraga Channel. All these individuals were genetically identified as G. punctata. Further, one juvenile of the girellid fish was collected at Y (Yokohama) to the north of the Uraga Channel in June 2014 (Table 4), and this individual was also genetically identified as $G$. punctata.

\section{Body size and $K$ of girellid juveniles}

In the research on Sagami Bay, the body size of 744 girellid juveniles genetically identified to species ranged from 12.3 to $46.8 \mathrm{~mm} \mathrm{SL}$. The body size of G. punctata $(n=676,12.3-46.5 \mathrm{~mm})$ was slightly smaller than that of
Table 4 Species composition and body size (SL) of juveniles of girellid fish collected in Kamogawa (B1), Tateyama (B2), and Yokohama (Y), based on PCR-RFLP of mtDNA

\begin{tabular}{|c|c|c|c|c|c|c|c|c|}
\hline \multirow[t]{3}{*}{ Month } & \multirow[t]{3}{*}{$n_{1}$} & \multirow[t]{3}{*}{$n_{2}$} & \multicolumn{3}{|c|}{ G. punctata } & \multicolumn{3}{|c|}{ G. leonina } \\
\hline & & & \multirow[t]{2}{*}{$n$} & \multicolumn{2}{|l|}{$\mathrm{SL}(\mathrm{mm})$} & \multirow[t]{2}{*}{$n$} & \multicolumn{2}{|l|}{$\mathrm{SL}(\mathrm{mm})$} \\
\hline & & & & Mean \pm SD & Min.-max. & & Mean \pm SD & Min.-max. \\
\hline \multicolumn{9}{|c|}{ Kamogawa (B1) } \\
\hline \multicolumn{9}{|l|}{2015} \\
\hline February & 0 & 0 & - & - & - & - & - & - \\
\hline April & 31 & 30 & 0 & - & - & 30 & $17.3 \pm 1.9$ & $14.5-22.9$ \\
\hline June & 200 & 30 & 30 & $19.3 \pm 2.9$ & $15.8-27.3$ & 0 & - & - \\
\hline August & 0 & 0 & - & - & - & - & - & - \\
\hline Total & 231 & 60 & 30 & $19.3 \pm 2.9$ & $15.8-27.3$ & 30 & $17.3 \pm 1.9$ & $14.5-22.9$ \\
\hline \multicolumn{9}{|l|}{ Tateyama (B2) } \\
\hline \multicolumn{9}{|l|}{2015} \\
\hline April & 0 & 0 & - & - & - & - & - & - \\
\hline June & 8 & 8 & 8 & $18.0 \pm 4.6$ & $13.6-25.4$ & 0 & - & - \\
\hline August & 0 & 0 & - & - & - & - & - & - \\
\hline Total & 8 & 8 & 8 & $18.0 \pm 4.6$ & $13.6-25.4$ & 0 & - & - \\
\hline \multicolumn{9}{|l|}{ Yokohama (Y) } \\
\hline \multicolumn{9}{|l|}{2014} \\
\hline June & 1 & 1 & 1 & 23.6 & - & 0 & - & - \\
\hline November & 0 & 0 & - & - & - & 0 & - & - \\
\hline Total & 1 & 1 & 1 & 23.6 & - & 0 & - & - \\
\hline
\end{tabular}

For abbreviations, see Table 1 
G. leonina ( $n=66,15.4-33.0 \mathrm{~mm})$ (Mann-Whitney's $U$-test, $p<0.01)$. Smaller (<20 mm SL) juveniles of $G$. punctata were collected at three stations $-\mathrm{S} 1$ (12.6-19.9 mm), S2 (12.3-19.9 mm) and S3 (15.3-19.8 mm); and of G. leonina at two-S1 (15.4-18.8 $\mathrm{mm})$ and S3 (17.9-19.8 $\mathrm{mm})$. Smaller juveniles $<20 \mathrm{~mm}$ SL were also collected from the coast of the Boso Peninsula: B1 (15.8-19.9 mm) and B2 (13.6-17.0 mm) for G. punctata and B1 (14.5-19.8 mm) for $G$. leonina.

It appears that the body size of juveniles of the girellid fish collected monthly in the eastern Sagami Bay (S1-S3) increased from spring to summer (Fig. 4). We examined the relationship between the time (elapsed days from 1 January) and the body length (SL) for the juveniles of the girellid fish collected monthly at S1-S4 (Table 5). In G. punctata, significant positive correlations were found at these stations except for the fish collected at S4 in 2016, but the correlation coefficients were not that high $(0.25-0.71)$ even when the correlations were significant. At $\mathrm{S} 1-\mathrm{S} 4$, the settlement-stage juveniles collected during April to July always included smaller juveniles $<20 \mathrm{~mm}$ SL.
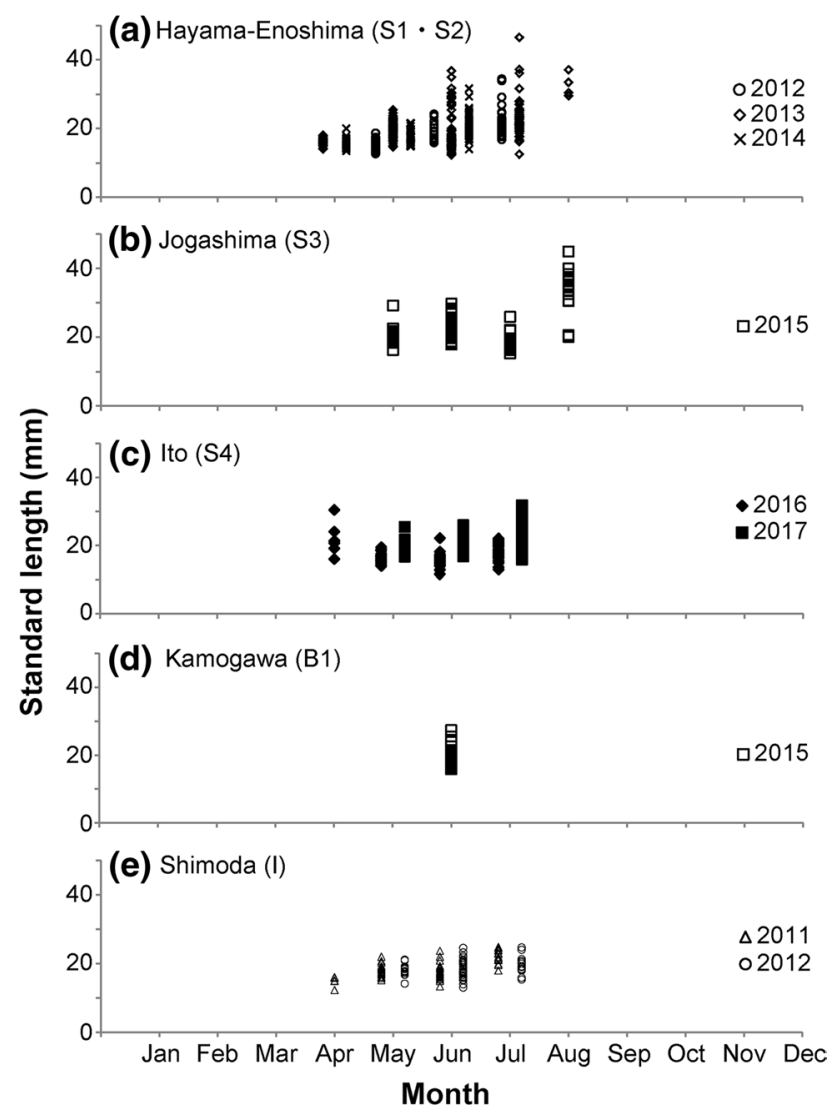

Fig. 4a-e Seasonal changes of SL in juveniles of G. punctata collected from the rocky shore. a Northeastern Sagami Bay: Hayama (S1) and Enoshima (S2). b Jogashima (S3). c Ito (S4). d Kamogawa (B1). e Shimoda (I) (data from Nakai et al. 2015)
Table 5 Correlation coefficients $(r)$ between elapsed days from 1 January and SL $(\mathrm{mm})$ of the girellid juveniles collected monthly at stations $\mathrm{S} 1-\mathrm{S} 4$ and I

\begin{tabular}{llll}
\hline Station & Year & G. punctata & G. leonina \\
\hline S1 & 2012 & $0.69(n=43, p<0.0001)^{*}$ & - \\
& 2013 & $0.43(n=119$, \\
& & - \\
& & $0.0001)^{*}$ & \\
& 2014 & $0.71(n=83, p<0.0001)^{*}$ & $0.82(n=4, p=0.18)$ \\
S2 & 2013 & $0.25(n=90, p<0.05)^{*}$ & $0.91(n=4, p=0.09)$ \\
S3 & 2015 & $0.49(n=91, p<0.0001)^{*}$ & - \\
S4 & 2016 & $-0.07(n=94, p=0.49)$ & - \\
& 2017 & $0.30(n=73, p<0.05)^{*}$ & $-0.59(n=36$, \\
& & & $p<0.0005)^{*}$ \\
I & 2011 & $0.54(n=83, p<0.0001)^{*}$ & $-0.27(n=39, p=0.10)$ \\
& 2012 & $0.23(n=66, p=0.06)$ & $0.32(n=94, p<0.0001)^{*}$ \\
\hline
\end{tabular}

Values were calculated for each year

* Statistically significant

In $G$. leonina, the time-related change of body size was unclear (Fig. 5). The juveniles collected at S1 in 2014 and S2 in 2013 showed high correlation coefficients (0.82-0.91),
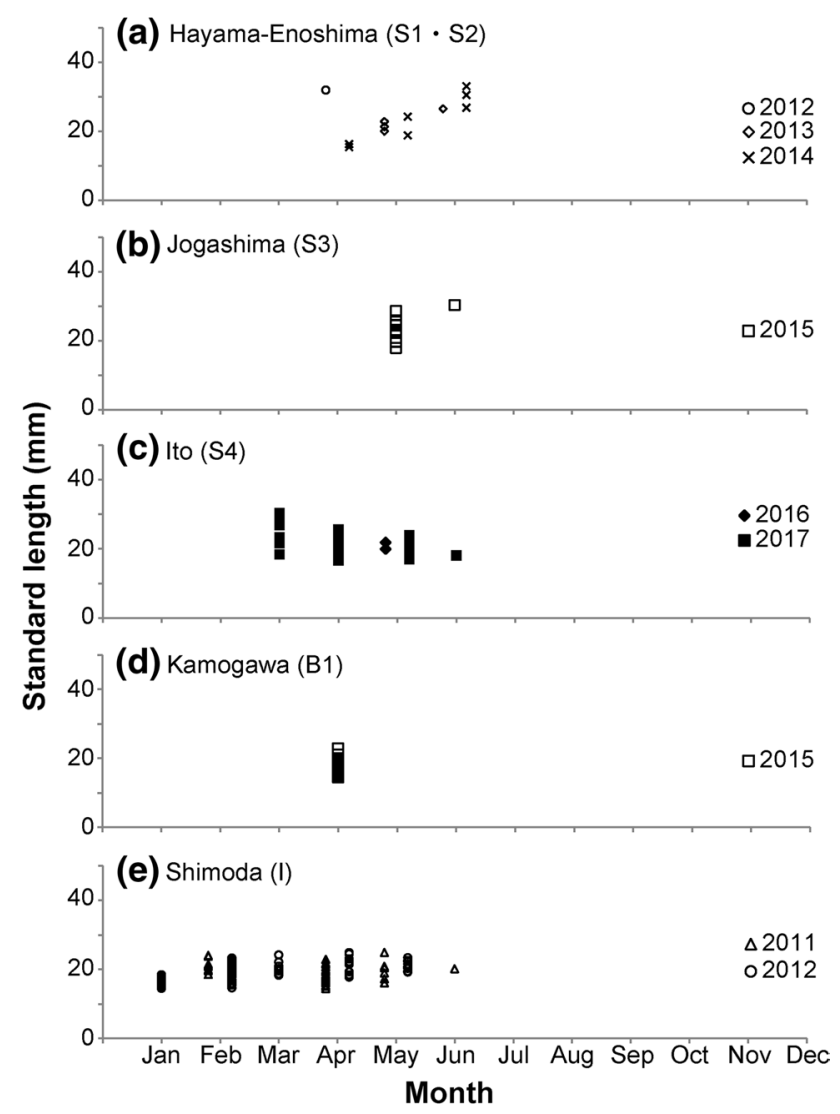

Fig. 5a-e Seasonal changes of SL in juveniles of G. leonina collected from the rocky shore. a Northeastern Sagami Bay: Hayama (S1) and Enoshima (S2). b Jogashima (S3). c Ito (S4). d Kamogawa (B1). e Shimoda (I) (data from Nakai et al. 2015) 
but these correlations were not significant $(p>0.05)$. On the contrary, the correlation in the juveniles collected at S4 in 2017 was significant $(p<0.0005)$, but the correlation coefficient was negative (-0.59). At S4, smaller juveniles $<20 \mathrm{~mm}$ SL were collected from March to June.

The $K$ of the girellid juveniles was significantly higher in $G$. punctata than in G. leonina in the northeastern Sagami Bay ( $\mathrm{S} 1$ and $\mathrm{S} 2, p<0.05$ ), the westernmost Sagami Bay (S4, $p<0.01$ ), and Sagami Nada (I, $p<0.01$ ) (Mann-Whitney's $U$-test; Fig. 6; Table 6). Contrary to this, the $K$ of the juveniles at the southernmost tip of the Miura Peninsula (S3) was significantly higher in $G$. leonina than in $G$. punctata $(p<0.05)$. There was no significant interspecific difference

(a) Hayama-Enoshima (S1 $\cdot \mathrm{S} 2)$
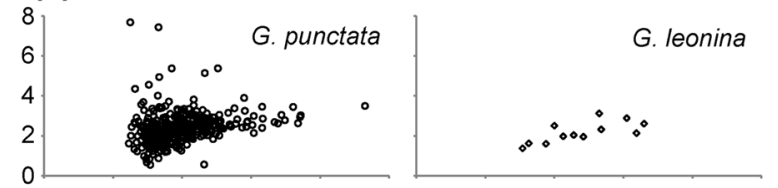

(b) Jogashima (S3)
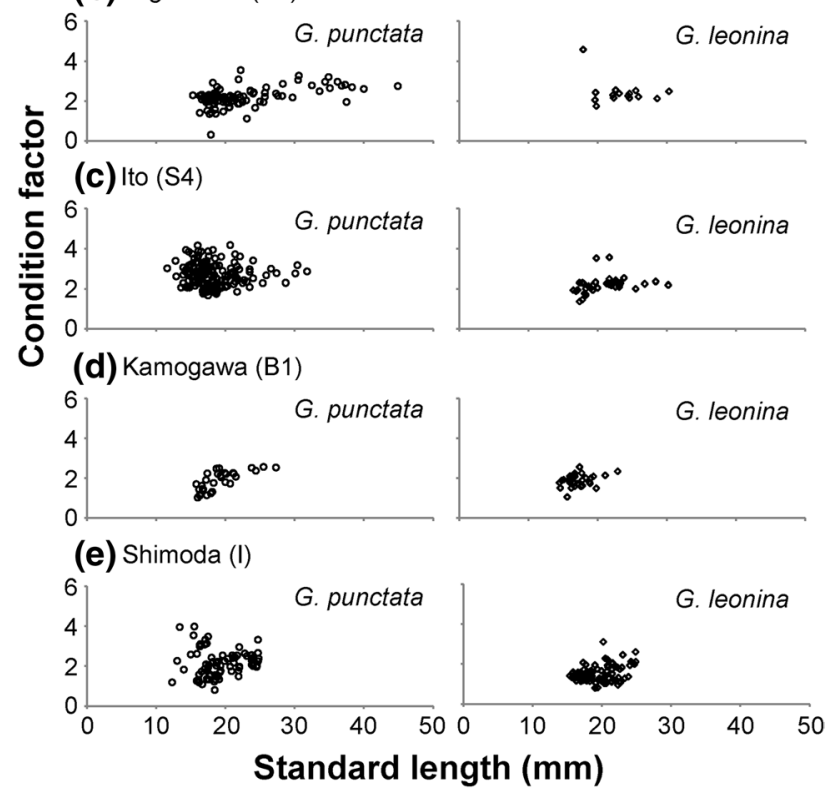

Fig. 6a-e Relationship between body size (SL) and condition factor. a Northeastern Sagami Bay: Hayama (S1) and Enoshima (S2). b Jogashima (S3). c Ito (S4). d Kamogawa (B1). e Shimoda (data from Nakai et al. 2015) $(p=0.93)$ only on the Pacific coast of the Boso Peninsula (B1).

\section{Discussion}

\section{Nursery ground use in G. punctata}

In Sagami Bay, juveniles of G. punctata were collected on the rocky shore from April to August. Particularly, the $G$. punctata juveniles ubiquitously appeared in May and June, suggesting that this area is utilized as the nursery ground by G. punctata. This occurrence season is highly consistent with the season previously reported for Sagami Nada (Shimoda, station I) by Nakai et al. (2015). The G. punctata juveniles in Sagami Nada were collected from drifting seaweeds in May and June and the rocky shore during April to July. Thus, it is likely that G. punctata juveniles in both Sagami Bay and Sagami Nada simultaneously settle on the rocky shore and live there until summer.

Smaller juveniles of G. punctata $<20 \mathrm{~mm}$ SL were constantly collected from April to July in Sagami Bay. Generally, larvae of G. punctata hatch out 53-60 h after insemination (Mito 1957), and planktonic juveniles are supposed to settle to the coastal bottom after a 1-month planktonic phase in the water column (Suzuki 2011). Therefore, we can calculate that smaller juveniles $<20 \mathrm{~mm}$ SL collected during April to July had been mainly born during March to June. In the maturity analysis of adults of G. punctata collected in the coastal waters of the northern Izu Islands, peak values of the gonadosomatic index (GSI) were found in April for both females and males (Nakai et al. 2015), and mature oocytes were found in the females collected in April and May by histological observation (Takai et al. 2017), suggesting that G. punctata spawns in the region during April to May. Therefore, the birth month (March-June) calculated for the smaller juveniles largely overlapped with the spawning season around the northern Izu Islands. The majority of the settlement-stage juveniles collected in May and June in Sagami Bay may be assumed to be born in April and May in the nearby area such as the Izu Peninsula waters.

On the other hand, the birth month of smaller juveniles collected in April was estimated to be March, assuming that the duration of planktonic life for G. punctata is 1 month. As
Table 6 The condition factor of G. punctata and G. leonina (tenth percentile-medianninetieth percentile), and the significance of the interspecific differences in Mann-Whitney's $U$-test

\begin{tabular}{llll}
\hline Station & G. punctata & G. leonina & Significance \\
\hline S1 and S2 & $1.52-2.32-3.09(n=346)$ & $1.50-1.95-2.21(n=7)$ & $p<0.05$ \\
S3 & $1.50-2.13-2.45(n=67)$ & $2.05-2.29-2.55(n=3)$ & $p<0.01$ \\
S4 & $1.97-2.66-3.51(n=159)$ & $1.74-2.17-2.46(n=34)$ & $p<0.01$ \\
B1 & $1.17-1.85-2.40(n=28)$ & $1.51-1.89-2.24(n=30)$ & $p=0.93$ \\
I & $1.33-2.16-3.08(n=99)$ & $1.11-1.46-2.01(n=106)$ & $p<0.01$ \\
\hline
\end{tabular}


mentioned above, the adult females in March were immature in the northern Izu-Islands waters, and therefore birth in March is improbable in the area. According to Maeda et al. (2002), GSI of G. punctata collected off the southern Kii Peninsula (Kushimoto) peaked in April, just like the peak season in the northern Izu Islands. It was thus considered that $G$. punctata spawns from April to May in the broad region off the Pacific coast of central Japan from the Izu Peninsula to the Kii Peninsula. Therefore, we inferred that the settlement-stage juveniles in April were born in the more upstream region of the Kuroshio Current in March. Takai et al. (2017) found that the GSI peaked in March for the G. punctata adults collected in the coastal waters of Tanegashima Island, located to the south of Kyushu district, and that the adult females had mature oocytes in March and April. This 1-month earlier maturity of G. punctata in the upstream region of the Kuroshio Current suggests that the juveniles collected in Sagami Bay in March originate from the population in the upper reaches of the Kuroshio Current. Recent genetic studies of the population structure of G. punctata reported that the DNA sequences of specimens collected from various areas around Japan were homogeneous, suggesting that the transport of the fish by ocean currents gives rise to the gene flow in G. punctata (Saito et al. 2008; Umino et al. 2009). The result in this study is highly consistent with the reported genetic structure of this species.

In the bimonthly research on the coast of the Boso Peninsula (B1 and B2), G. punctata was collected in June only, and no G. punctata juveniles were collected in February, April, or August (Fig. 4d). In June, a total of 208 girellid juveniles were collected at B1 and B2 and all the 38 juveniles genetically analyzed were identified as $G$. punctata. This suggests that the juveniles of G. punctata temporarily utilize the coastal waters of the Boso Peninsula as a nursery ground in early summer for a short period.

\section{Nursery ground use in G. leonina}

The settlement-stage juveniles of G. leonina collected on the rocky shore in Sagami Bay totaled 66 individuals only, accounting for only $8.9 \%$ of all the 744 juveniles genetically analyzed for species identification. The occurrence season of the settlement-stage juveniles was shorter in G. leonina except for the eastern edge of the Izu Peninsula (station S4), lasting about 3 months from April to June. An individual was collected in July at S5 (Oiso), but its body size was large at $46.8 \mathrm{~mm} \mathrm{SL}$ and therefore it is likely that this individual had already stayed there for several months after settlement.

Such a short duration of the occurrence of $G$. leonina juveniles in Sagami Bay contrasts with their long-term occurrence in Sagami Nada around Shimoda (station I). In Sagami Nada, the juveniles were collected for half a year from January to June, and particularly the girellid juveniles during January to March consisted only of G. leonina (Nakai et al. 2015). Thus, the geographical difference in the distribution of the $G$. leonina juveniles can be characterized by an abundant catch and long duration of occurrence in Sagami Nada, and a sparse catch and absence during wintertime in Sagami Bay. It is likely that this difference reflects differences of the ambient water temperature in the coastal zone. In general, the optimal water temperature for the juveniles of G. leonina ranges from 25.1 to $28.3^{\circ} \mathrm{C}$, with an optimum of $26.1^{\circ} \mathrm{C}$, and a low temperature of $8.0-11.8^{\circ} \mathrm{C}$ is fatal to the juveniles (Shimo et al. 2000). According to continuous observation of water temperature on the coast of Shimoda [station I (Yoshihara and Takashiro 2009)], the daily data at 10 a.m. during 2003 to 2007 averaged $15.3{ }^{\circ} \mathrm{C}$ in January, $14.1{ }^{\circ} \mathrm{C}$ in February and $14.5^{\circ} \mathrm{C}$ in March. By contrast, the water temperature on the coast of S2 (Enoshima) has been reported to decrease to about $11^{\circ} \mathrm{C}$ in February (Yoshiyasu et al. 2004; Ueda and Ara 2015). We infer that the G. leonina juveniles in Sagami Bay cannot survive such a low temperature during wintertime, in contrast to the juveniles growing in the warmer water in Sagami Nada where the Kuroshio Current flows along the coast.

At the eastern edge of the Izu Peninsula (station S4), the juveniles of G. leonina appeared in March, earlier than the occurrence of the juveniles in the eastern area of Sagami Bay (Fig. 3). It is well known that warm water from the Kuroshio Current often intrudes into Sagami Bay through Sagami Nada and influences the currents and the circulation of water in the bay (Hinata et al. 2003). The environment of S4 would be strongly influenced by the intrusion of the warm water of the Kuroshio Current, since this station is located around the mouth of the intrusion. The earlier occurrence and relatively abundant catch of the G. leonina juveniles at this station likely reflect the influence of the warm water of the Kuroshio Current.

On the Pacific coast of the Boso Peninsula (station B1), the juveniles of G. leonina were collected in April only. All the girellid juveniles genetically analyzed were identified as G. leonina in the month. This result suggests that the coastal zone of the Boso Peninsula is temporarily utilized as a nursery for G. leonina in spring. In Sagami Bay, we collected only 66 juveniles of $G$. leonina by monthly sampling at multiple stations over the period of 2012-2017, while the 30 juveniles of $G$. leonina on the Pacific coast of the Boso Peninsula were collected at one time point in April 2015. Sagami Bay is not directly exposed to the Kuroshio Current, in contrast to the peninsulas of Izu and Boso. It is probable that the Kuroshio Current plays an important role in the transport and settlement of juveniles of G. leonina.

Takai et al. (2017) reported that the gonads of adult $G$. leonina collected off Tanegashima Island were higher in GSI than those collected around the northern Izu Islands, and the oogenesis of the G. leonina adults was more advanced 
in Tanegashima Island waters. Based on these results, Takai et al. (2017) expected the spawning ground of G. leonina to be located in the upper reaches of the Kuroshio Current, much further upstream of Tanegashima Island. We expect that planktonic larvae and juveniles of G. leonina are transported over a long distance from the upper reaches of the Kuroshio Current, and settle on the rocky coast of the KantoIzu region along the path of the Kuroshio Current.

\section{Importance of the Kuroshio Current to the reproduction of girellid fish}

In Sagami Bay, the juveniles of G. punctata were collected in abundance in spring and summer, while the juveniles of $G$. leonina were rarely collected throughout the research period. We infer that this contrasting result reflects the interspecific difference in the influence of the Kuroshio Current on the transport of the girellid juveniles. It has been suggested that the spawning grounds of $G$. punctata exist in various places around Kyushu and the southern part of Honshu (Mizue and Mikami 1960; Maeda et al. 2002; Nakai et al. 2015; Takai et al. 2017). Therefore, a large portion of planktonic juveniles of G. punctata are likely transported by the local current and eddy, and locally settle on the coastal bottom near the spawning ground. On the other hand, the spawning ground of G. leonina has not been reported yet, and in our previous research we expected the adults of G. leonina to spawn in the upstream region of the Kuroshio Current on the basis of maturity analysis (Takai et al. 2017). If eggs and planktonic larvae and juveniles were mostly transported a long distance by the Kuroshio Current from its upstream region, the G. leonina juveniles could more easily settle on the bottom near the path of the Kuroshio Current and would not easily reach the inner part of Sagami Bay which is not directly exposed to the Kuroshio Current.

In G. leonina, there was no significant increase of body size with time in either Sagami Bay or Sagami Nada (Fig. 5). This result supports the probable long-distance transport by the Kuroshio Current. The planktonic larvae and juveniles of G. leonina are likely to grow in Kuroshio Current water and finally settle on the coastal bottom by chance. The intermittent settlement of size-varied juveniles would constantly disrupt the body size distributions of the juveniles on each rocky shore. As a result, we cannot observe the growth process of the sedentary juveniles on the rocky shore.

The $K$ of the juveniles was significantly higher in $G$. punctata than in G. leonina in the coastal waters of the Izu Peninsula (S4 and I) and the northeastern area of Sagami Bay (S1 and S2) (Fig. 6; Table 6). As mentioned above, warm water from the Kuroshio Current often intrudes into Sagami Bay through Sagami Nada (Hinata et al. 2003). In general, the water of the Kuroshio Current is depleted in dissolved and particulate organic matter (Teramoto 1987), relative to the coastal water with higher productivity. The planktonic life in such oligotrophic water could cause the starvation of post-larvae and juveniles, and result in the decrease of their $K$. Significantly lower $K$ s of $G$. leonina also support the probable long-distance transport by the Kuroshio Current.

By contrast, in the eastern side of the study area, the $K$ of $G$. leonina was significantly higher than that of $G$. punctata at the tip of the Miura Peninsula (S3) or almost equal to that of G. punctata on the Pacific side of the Boso Peninsula (B1) (Fig. 6; Table 6). It is well known that nutrient-rich water from the Oyashio Current intrudes into Sagami Bay along the coast of the Boso Peninsula (Senjyu et al. 1998). The ocean dynamics differ between the eastern and western zones of Sagami Bay. We infer that the girellid juveniles around the Boso Peninsula arrive at the rocky shore through a distinctive transport pathway in the Oyashio-Kuroshio interfrontal zone.

The fate of the G. leonina juveniles settling in the coastal waters of the Izu Peninsula is unclear, but we infer that a substantial number of juveniles distantly migrate to the upper reaches of the Kuroshio Current across the Kuroshio recirculation region. Simulation modeling by Miyake et al. (2015) showed that phyllosoma larvae of the Japanese spiny lobster Panulirus japonicus can be successfully transported from the coastal waters of Japan to the upper reaches of the Kuroshio Current across the Kuroshio Extension and the Kuroshio recirculation region by vertically migrating and utilizing suitable current in the subsurface layer. It is likely that the G. leonina juveniles can also utilize the same transport pathway to reach the upper reaches of the Kuroshio Current. Generally, the catch of $G$. leonina adults is abundant in the coastal waters of the Tanegashima Island (Takai et al. 2017), in contrast to the scarce catch in the northern Izu-Islands waters (Nakai et al. 2015). We expect that the adults of $G$. leonina are densely distributed in the marginal region of the East China Sea and spawn in the upper reaches of the Kuroshio Current.

In the present study, we showed that the distribution patterns of the settlement-stage juveniles were extremely different between G. punctata and G. leonina, and inferred that this clear-cut difference in their geographical distributions would be closely related to the interspecific difference in the transport system of eggs, planktonic larvae and juveniles. We hypothesize that $G$. leonina depends on long-distance transport by the Kuroshio Current in its reproduction, while G. punctata is more dependent on the local current and eddy for such transport. In other words, we hypothesize that the Kuroshio Current strongly influences the reproductive success of G. leonina. In order to test this hypothesis, future work is needed to accurately examine the spawning grounds and spawning season of $G$. leonina, by examining the sexual 
maturation process of the G. leonina adults collected from the upper reaches of the Kuroshio Current.

Acknowledgments We thank T. Higuchi, H. Takahara, K. Inoue, R. Saiki, Y. Matsushita, Y. Nakai, K. Otsuka, Y. Ogino, Y. Kato, M. Takahashi, S. Misawa, R. Shimazaki, and H. Fukuoka for their cooperation with the sampling and the dissection. We are also grateful to K. Tsukamoto and T. Higuchi for their valuable comments and information about the migration of girellid fish. This study was financially supported by research grants during 2011-2013 from the College of Bioresource Sciences, Nihon University.

Open Access This article is distributed under the terms of the Creative Commons Attribution 4.0 International License (http://creativeco mmons.org/licenses/by/4.0/), which permits unrestricted use, distribution, and reproduction in any medium, provided you give appropriate credit to the original author(s) and the source, provide a link to the Creative Commons license, and indicate if changes were made.

\section{References}

Araga C (1997) Girellidae. In: Okamura O, Amaoka K (eds) Sea fishes of Japan. Yama-kei, Tokyo, p 414

Fujita S, Takahashi I, Niimi K (2000) Use of iridophore pigmentation patterns to separate juveniles of two Girella species (Girellidae). Ichthyol Res 47:397-400

Hinata H, Miyano M, Yanagi T, Ishimaru T, Kasuya T, Kawamura H (2003) Short-period fluctuations of surface circulation in Sagami Bay induced by the Kuroshio Warm Water Intrusion through Ooshima West Channel. Oceanogr Jpn 12:167-184 (in Japanese)

Itoi S, Saito T, Shimojo M, Washio S, Sugita H (2007) Identification of Girella punctata and G. leonina by PCR-RFLP analysis. ICES J Mar Sci 64:328-331

Konishi Y (2014a) Girellidae. Girella punctata. In: Okiyama M (ed) An atlas of early stage fishes in Japan, 2nd edn. Tokai University Press, Tokyo, pp 955-956 (in Japanese)

Konishi Y (2014b) Girellidae. Girella leonina. In: Okiyama M (ed) An atlas of early stage fishes in Japan, 2nd edn. Tokai University Press, Tokyo, p 957

Maeda M, Kimura S, Nakabo T (2002) Age and growth of Girella punctata in Kushimoto, Wakayama Prefecture, Japan. Nippon Suisan Gakkaishi 68:859-865 (in Japanese)

Mano N, Itoi S (2011) Encounter between G. punctata and G. leonina. In: Umino T, Yoshida M, Itoi S (eds) Girellid fish-fishing? Science? Kouseisha-Kouseikaku, Tokyo, pp 19-24 (in Japanese)

Mito S (1957) Egg development and hatched larvae of Girella punctata Gray (Girellidae, Teleostei). Ichthyol Res 6:105-108

Miyake Y, Kimura S, Itoh S, Chow S, Murakami K, Katayama S, Tkeshige A, Nakata H (2015) Roles of vertical behavior in the open-ocean migration of teleplanic larvae: a modeling approach to the larval transport of Japanese spiny lobster. Mar Ecol Prog Ser 539:93-109
Mizue K, Mikami T (1960) Studies on the maturation and the seasonal cycle in the gonad of Girella punctata. Bull Fac Nagasaki Univ 9:18-32

Nakabo T (2000) Girellidae. In: Nakabo T (ed) Fishes of Japan with pictorial keys to the species, 2nd edn. Tokai University Press, Tokyo, p 959

Nakai S, Higuchi T, Iino Y, Itoi S, Sugita H, Takai N (2015) Spawning ecology of Girella punctata and G. leonina (Perciformes: Girellidae) in the coastal waters of the Izu Peninsula, Japan. Coast Mar Sci 38:12-20

Palumbi S, Martin A, Romano S, McMillan W O, Stice L, Grabowski G (1991) The simple fool's Guide to PCR, version 2. Department of Zoology and Kewalo Marine Laboratory, University of Hawaii, Honolulu

Saito T, Washio S, Dairiki K, Shimojo M, Itoi S, Sugita H (2008) High gene flow in Girella punctata (Perciformes, Kyphosidae) among the Japanese Islands inferred from partial sequence of the control region in mitochondrial DNA. J Fish Biol 73:1937-1945

Senjyu T, Asano N, Matsuyama M, Ishimaru T (1998) Intrusion events of the intermediate Oyashio Water into Sagami Bay, Japan. J Oceanogr 54:29-44

Sezaki K, Begum AR, Wongrat P, Srivastava PM, SriKantha S, Kikuchi K, Ishihara H, Tanaka S, Taniuchi T, Watabe S (1999) Molecular phylogeny of Asian freshwater and marine stingrays based on the DNA nucleotide and deduced amino acid sequences of the cytochrome $b$ gene. Fish Sci 65:563-570

Shimo S, Akimoto Y, Takahama H (2000) Bibliographical study of the thermal on marine organisms. Rep Mar Ecol Res Inst 2:1-351

Suzuki N (2011) Morphological change in juveniles of G. punctata. In: Umino T, Yoshida M, Itoi S (eds) Girellid fish-fishing? Science? Kouseisha-Kouseikaku, Tokyo, pp 13-18 (in Japanese)

Takai N, Ito T, Iino Y, Yamamoto T, Suzuki M, Asahina K, Itoi S, Nakai S, Mano N, Huang M, Sugita H (2017) Sexual maturation of Girella punctata and G. leonina (Perciformes: Girellidae) in the neritic sea off the Pacific coast of Japan. Coast Mar Sci 40:7-16

Teramoto T (1987) Kuroshio. In: Wadati K (ed) Encyclopedia of oceanography. Tokyodou press, Tokyo, pp 182-192 (in Japanese)

Ueda I, Ara K (2015) Inhabitation and physicochemical factors of the green mussel Perna viridis at Enoshima Island, Sagami Bay, Central Japan. Nat Hist Rep Kanagawa 36:31-36

Umino T, Kajihara T, Shiozaki H, Ohkawa T, Jeong DS, Ohara K (2009) Wild stock structure of G. punctata in Japan revealed shallow genetic differentiation but subtle substructure in subsidiary distributions. Fish Sci 75:909-919

Yagishita N, Nakabo T (2000) Revision of the genus Girella (Girellidae) from East Asia. Ichthyol Res 47:119-135

Yoshihara K, Takashiro H (2009) Comparison with monthly average water temperature over the past 5 years (2003 to 2007). In: Yoshihara K (ed) Tanoura Bay coastal observation result, no. 17. Department of Marine Science and Resources, College of Bioresource Sciences, Nihon University, Kanagawa, p 6 (in Japanese)

Yoshiyasu H, Ueda I, Asahina K (2004) Annual reproductive cycle of the green mussel Perna viridis (L.) at Enoshima Island, Sagami Bay, Japan. Sessile Organ 21:19-26 